\title{
More than half of UK dental practices rely on Government loans
}

$52 \%$ of UK dental practices have relied on either CIBLS (Coronavirus Business Interruption Loan Scheme) or BBLS (Bounce Back Loan Scheme) from the government.

The survey, carried out by NASDAL (National Association of Specialist Dental Accountants and Lawyers) last month and a sample of 121 practices (with a total fee income of $£ 88$ million) was taken from NASDAL accountant member practice owning clients on a random sampling basis. The survey found that:

$\rightarrow 11 \%$ of practices have taken out CBILS loans, mainly private practices

$\rightarrow$ The average CBILS loan is $£ 105 \mathrm{k}$ ( $12 \%$ of fee income)

$\rightarrow 41 \%$ of practices have taken out BBLS loans, covering all types of practices.

$\rightarrow$ The average BBLS loan is $£ 49 \mathrm{k}$ ( $7 \%$ of fee income).

$\rightarrow$ The average loan is $£ 32 \mathrm{k}$ ( $4 \%$ of fee income) and overall, $52 \%$ of dental practices have taken advantage of Government-backed COVID-19 loans.

As part of a short life working group (SLWG) headed up by Deputy CDO England, Jason Wong, NASDAL, alongside other key stakeholders, reported to the CDO to investigate the validity of the claim 'there will be a dearth of dental practices on the high street in 18 months' time.' The group made nine recommendations to the $\mathrm{CDO}$ and government, which were:

1. An extension of the Coronavirus Job

Retention Scheme for the dental sector
2. An extension of the maximum repayment term (currently 6 years) for both the Coronavirus Business Interruption Loan Scheme (CBILS), and the Bounce Back Loan Scheme (BBLS) applicable across the breath of the dental sector

3. Eligibility for business rate relief for all dental practices

4. Eligibility for Retail, Hospitality and Leisure Grant (RHLGF) for the dental sector

5. A support package for dental laboratories that service NHS dental practices

6. A Government guaranteed loan support scheme to underpin lenders' confidence in supporting dental practices and dental laboratories at risk

7. A Government commitment to target additional funding toward an expanded NHS dental provision to address inequalities by:

a. Commissioning additional dental capacity for routine dental care and increase patient access

b. Commissioning additional capability and capacity for non-mandatory services; to include domiciliary services for care homes and community settings, sedation services, advanced restorative work to address evidenced needs (e.g. endodontics)

c. Flexible commissioning to support prevention initiatives

8. Funding for urgent research into the fallow time post dental aerosol-generating procedures
9. For the General Dental Council (GDC) to return the 20/21 Annual Retention Fee (ARF) to Dental Technicians.

Alan Suggett, specialist dental accountant and partner in UNW LLP who compiles the goodwill survey, commented: 'These findings don't surprise me and reflect what I have found when speaking to dental clients. The CBILS application process was particularly arduous and difficult and this meant that in my experience, those practices that applied for CBILS loans really did need the funds. BBLS however, required just a couple of ticks and the money was in the account 48 hours later. I suspect that a large number of applicants did so on a 'just in case' basis and will be happy to pay the money back in full next year.

'One of the major concerns that NASDAL had when we reported to the short life working group (SLWG) headed up by Deputy CDO England, Jason Wong, was that most dental practices are fundamentally sound businesses and to see a good number in potential difficulty purely because of capital loan repayments, is a real concern. That is why it was key for us that in the recommendations, a government guaranteed loan support scheme to underpin lenders' confidence in supporting dental practices and dental laboratories at risk was included.

'When the CIBLS and BBLS repayments become due next year, we will see how many dentists and practices are in difficulty'.

\section{Workforce 'critical to tackling unacceptable high levels of dental decay'}

The current number of specialists in paediatric dentistry is insufficient to meet the oral health needs of children and young people, according to The British Society of Paediatric Dentistry (BSPD).

The concern on the shortfall of specialists follows news from the Faculty of Dental Surgery at the Royal College of Surgeons of England (FDS RCSEng) that highlights the unacceptably high number of dental extractions under general anaesthetic caused by dental decay.

While supporting the call from FDS for the roll-out of supervised tooth brushing schemes in early years settings and for a renewed commitment to sugar taxes, BSPD spokesperson Claire Stevens highlights the complexity of the current challenges facing the dental profession.

Dr Stevens said: 'COVID-19 has deepened the challenges faced by the dental profession. Post lockdown, dental treatment has been successfully restarted, yet there is an estimated reduction in capacity of $50-65 \%$ due to essential measures to minimise the risk of viral transmission and protect staff and patients.

'Sadly, the number of children requiring hospital-based treatment caused by dental decay is going to remain constant as we have no choice but to anaesthetise very young children who need extensive restorations or extractions.

'However, at the same time as ensuring we have the workforce to carry out these treatments, we also need prevention programmes to help families rethink children's diets and reduce sugar consumption. We would like to ensure that all children are regularly brushing their teeth both at home while the very young should experience supervised toothbrushing programmes in early years settings.' 